\title{
Public Relation Campaign Towards Forming Positive Approaches for green Spatial Developtmen at Adiwiyata School in Bangka Regency
}

\author{
Shulby Yozar Aryadi ${ }^{1}$, Kornelia Johana Dacosta ${ }^{2}$, Gusmulyana ${ }^{3}$, Ida Royani Damayanti ${ }^{4}$ \\ \{yozar.aryadi@ stisipolp12.ac.id ${ }^{1}$, kornelia.johana@undira.ac.id ${ }^{2}$, gusmulyana@gmail.com ${ }^{3}$, \\ ida.damayanti@undira.ac.id ${ }^{4}$ \} \\ STISIPOL Pahlawan 12, Indonesia ${ }^{1}$, Universitas Dian Nusantara, Indonesia ${ }^{2}$, Universitas Dian Nusantara, \\ Indonesia $^{3}$, Universitas Dian Nusantara, Indonesia ${ }^{4}$
}

\begin{abstract}
For several decades, environmental issues have been a topic of serious discussion within the global community, including Indonesia. Indonesia's forests, which were once considered as one of the world's most important lungs are today no longer able to claim this status due to their widespread destruction and damage to their extensive ecosystems. This destruction has also taken place in Bangka Province, due not only due to the clearing of land for plantations and even more so for mining. The increasingly critical condition of the forest environment has motivated the provincial government of Bangka Belitung to carry out various environmental conservation programs involving all elements of the community as well as human resources, especially students. The purpose of this abstract is to promote research to determine how Adiwiyata students interpret the green spatial development program being undertaken by the Provincial Government Environmental. This research used qualitative methods with a descriptive method approach.
\end{abstract}

Keyword: Insights of the Academic Community, Public Relations Campaign, Adiwiyata,

\section{Introduction}

The issue of the environment has always been a topic of discussion for the global community which requires serious handling by the community, including Indonesia. Indonesia, which was once considered one of the lungs of the world, is now no longer able to hold its status due to the increasing destruction of forests and the ecosystem in them. Forest Watch Indonesia (FWI) stated that in 2009 to 2013 the deforestation rate of 1.1 million hectares increased, from 2013 to 2017 it increased to 1.47 million hectares. Forest destruction has also occurred in Bangka Belitung. The act of logging the forest is not solely due to the clearing of plantation land but mostly due to the clearing of mining land, because Bangka Belitung is known as the largest mining-producing island in Indonesia. Moreover, the ex-tin mining excavation requires a long time for recovery so that it can be reclaimed or reforested due to changes in soil nutrients and radio pollution caused by tin mining. Therefore, the forest is also added a little as a producer of oxygen needed in human life

Based on online coverage of environmental losses from forests caused by various illegal activities, such as cutting trees without obtaining a permit from threatening parties, illegal tin sand mining, and activities that can damage other ecosystems. It is known from the records of the 
Forestry Service (Dishut) of the Bangka Belitung Islands Province, that around 200,000 hectares of the total area of 657,000 hectares of forest in Bangka Belitung were damaged. https://republika.co.id/berita/q3qdvl459/200-ribu-hektare-hutan-di-bangka-belitung-rusak.

The increasingly critical condition of the forest environment has made the local government of Bangka Belitung strive to carry out various environmental conservation programs that involve all elements of society, especially the younger generation, namely students. One of them is the development of green open spaces in schools from Kindergarten level to Senior High School level. Schools with environmental insight or known to the community are developed in an effort to internalize environmental values in all activities at school. Schools with a green and shady ecological appearance are expected to be able to become a means of learning infrastructure about the importance of improving the environment as one of the hearts of human life so that it can be regulated wisely and wisely. Not only in the form of learning, but more than that how school members create green quality in their schools in creative ways, innovative and sustainable.

The role of communication in humans related to the environment has been carried out by various studies that examine the environment, methods of public participation in environmental decisions, environmental rhetoric, risk communication, environmental conflict and resolution, green space campaigns, and a picture of the environment in popular culture [1]. Environmental issues are also one of the most important research fields of the 21st century.

Campaigns regarding the development of green spatial planning in Adiwiyata schools in Bangka Regency have been carried out in particular by the Bangka Regency Environmental Service through various media such as direct socialization to Public Service Ads with mass media. In addition, to motivate the development of this environmentally based school, Adiwiyata awards were also given starting from the district to national levels. To build awareness itself, the formulation of messages conveyed through campaigns must have ethical values in building perceptions so that they can change positive attitudes towards programs made by DLH and related parties such as academics and environmental communities in interpreting how important it is to protect the environment

Campaign can be broadly defined as strategic action, which involves communication, which is carried out for a specific purpose, and environmental campaign must lead to positive education. This form of environmental communication is also known as advocacy, which aims to persuade, make policies, design ideas, or a certain set of values. Leslie B. Sndyder stated that A communication is an organized communicator activity, directed at a particular goal. He stated that broadly speaking, the PR campaign is an organized communication activity, directly aimed at specific audiences, and within a predetermined period of time with a specific purpose.

Adiwiyata award itself is based on Regulation of the Minister of Environment and Forestry of the Republic of Indonesia Number P.53 of 2019. Adiwiyata is an award given by the Government, Provincial Government and District / City Government to schools that have succeeded in implementing environmental care and culture movements in schools. But of course, to get the award, the school must go through the administrative selection stage to fulfill the Adiwiyata school criteria, its call Caring and Cultured Healthy Environment movement (PBLHS)

The idea of the campaign idea carried out by the Bangka Regency Environmental Agency, is not to get an award as a symbol of supremacy which is its main goal but rather to increase awareness and positive attitudes of the community, especially students in developing green spatial planning in the school environment where they study. This positive attitude is expected not only in the school environment but can spread widely to the community with the key to participation is the community itself as a form of participation in protecting the environment. To ensure that every movement or effort that leads to social change, behavior change requires an agent of change or opinion leader who with their influence can move the community and usually the agent of change is on average the 
figures a very influential figure who has always been a role model, in this case DLH collaborated with several actors to campaign for the Adiwiyata program, namely NGOs and academics through schools in Bangka,.It is hoped that through the realm of education, the campaign ideas carried out by the Bangka Regency Environment Agency will increase public awareness to protect the environment in a better direction. Mr. Heru Prayoga explains that the purpose of DLH Bangka Regency Government is to campaign Adiwiyata School to schools in Bangka is to increased motivation wheter schools and increase awarnes by developting environmentally based and sustainable through the Adiwiyata program.

To find out how this positive attitude can be measured requires research so that it can be seen from a program including the Public Relations campaign conducted by DLH Bangka Regency. Thus, based on the background of the existing problems, the researchers are interested in making a study with the title "Perceptions of Schools of Bangka Regency Government Environmental PR Campaign Activities in Forming a Positive Attitude for Green Spatial Development in Adiwiyata Schools in Bangka Regency. Research Focused, The focus this research is to (i) How the communication conveyed through the Public Relations Campaign carried out by the Bangka Regency Environmental Service in forming a positive attitude towards the development of green spatial planning at Adiwiyata schools. (ii) What is the interpretation received by the Adiwiyata school community regarding the green spatial development program campaigned through the Adiwiyata school by the Bangka Regency Environmental Service. (iii) How to build ethical values contained in the Public Relations Campaign in building a positive attitude towards the green spatial development program at Adiwiyata School. Research Objectives, the purpose of this study is to (i) describe the communication delivered by the Public Relations campaign of the Bangka Regency Environmental Service in forming a positive attitude towards the development of green space in Adiwiyata schools through the Ostergaard campaign model. (ii)To find out how Adiwiyata school students interpret the green spatial development program campaigned by the Environment Agency. (iii) to explore the ethical values construct through messages and to create a positive attitude towards the green spatial development program campaigned by the Bangka Regency Environmental Service

\section{Literature Review}

In principle, communication is a process that explains who, what he says, through what channels, to whom he delivers it, then what is the result of the message he delivers and what is the result? Who, Said What, On Which channel, To Whom, With what effect [2] According to The goal of communication activity that communicators want to convey to the communicant, has four aspect, such changing attitudes (to change the attitude), changing opinions or opinions (to change the opinion), then change behavior (to change behavior) and the final goal is to change society (to change the society) including values, social attitudes, and behavior patterns, as well as the system that applies to society itself [3].

Environmental Communication, is study of communication science that specifically discusses the environment. According to[4] environmental communication is a pragmatic and constitutive of providing an understanding of the environment to the public regarding the environment. In the practical of environmental communication scope, discusses strategic message packaging to encourage knowledge to increase awareness and public participation in protecting the environment. In conceptual level, environmental communication studies contribute to theories about human 
communication itself. For example, the focus lies on the role of human communication, art, symbols, and in defining the human relationship with nature as the most obvious example that human communication mediates or negotiates our relationship to, and understands the world.

Campaign, Acording to [5] further explained that a campaign is a series of planned communication efforts and actions to get support from a large number of audiences carried out by a person or group of people in an organized manner in a decision-making process and carried out continuously within a certain period of time.

Campaign Type Based on Orientation (i) Product Oriented Campaigns These are product oriented campaigns. This type of campaign is generally carried out within a commercial business environment. This campaign aims to build a positive image of the products introduced to the public. (ii) Candidate Oriented Campaigns These are candidate-oriented campaigns. These campaigns usually have a background of passion for political gain. For example the election campaign, the election campaign. (iii) Ideologically or Cause Oriented Campaigns specifically social in nature. As Kotler has explained, social change campaigns aim to deal with various social problems by changing people's views, attitudes and behaviors (Maxmanroe, 2018).

Green Open Space Concept, according to Law Number 26 of 2007 concerning Spatial Planning, green open space is defined as an elongated area / pathway and/or group, which is as a place for plants whether they grow naturally or are intentionally planted. Public green open space is an open space that is owned and managed by the city government which is used for the benefit of the general public. Which includes public green open spaces, among others, are city parks, public burial parks, and green lanes along roads, rivers, and beaches. Which includes private green open space, among others, is the yard of the house/building owned by the community or private plants planted with plants. The proportion of 30 (thirty) percent is the minimum measure to ensure the balance of the urban ecosystem, both the balance of the hydrological system and the microlimat system, as well as other ecological systems, which in turn will increase the function and proportion of green open space in cities, government, society, and the private sector, to plant plants on their own buildings. The proportion of public green open space covering an area of at least 20 (twenty) percent provided by the municipal government is intended so that the minimum proportion of green open space can be more guaranteed to achieve it so as to allow its widespread use by the community [6].

Adiwiyata School Program Concept, Adiwiyata derived from the word "Adi" which means good, big, perfect, ideal, while "Wiyata" is a place for someone who gets knowledge, norms, ethics in social life. Adiwiyata is an ideal place for someone to gain knowledge, norms, and ethics in social life with the environment. Meanwhile, the Adiwiyata program is a program to create schools that care about the environment. Adiwiyata is a character building program, behavior and culture that cares for the environment. The Adiwiyata school program is intended to encourage the creation of knowledge and awareness of school members about cultured and environmentally friendly schools (Adiwiyata). The aim this program is to increase the awareness and capacity of schools to realize Adiwiyata school, as well as increase institutional and human resource capacity in the management of the Adiwiyata program and increase school participation in environmental conservation and management efforts based on Law no. 32 of 2009 concerning Protection and Management of the Environment and Minister of Environment Regulation no. 5 of 2013 concerning Guidelines for the Implementation of the Adiwiyata Program.

The basic principles of the Adiwiyata school: (i) Educative, (educative) provides education about environmental protection and management. (ii) Participatory, (participatory) school members are involved in all Adiwiyata activities starting from the planning, implementation, evaluation 
processes according to their respective responsibilities and roles. (iii) Sustainable, all activities must be carried out in a planned and continuous manner and comprehensively.

Basic Concepts of Perception, Perception is one of the important psychological aspects for humans in responding to the presence of various aspects and symptoms around them. Etymologically, the word perception or in English perception comes from Latin, namely perceptio, which means to accept or take. Perception in the narrow sense is vision, the way a person sees, while in the broadest sense it is a view or understanding, namely the way a person views or interprets.(Robin Kramer, 2013) defines perception as a process that individuals take to organize and interpret their sense impressions in order to give meaning to their environment. [8] provides a definition of perception as an interpretation of what individuals perceive or feel.

\section{Methods}

Methodology. This research will be conducted using qualitative research methods, with a descriptive approach because this approach is best able to make observations in a natural and social setting. The purpose of researchers using descriptive research is to produce an accurate picture of a phenomenon and the mechanism of a process, which will explain a set of stages of the research process. Research Focus, the focus of the research carried out in how the campaign by the Environmental Agency and what values are in the campaign and how the interpretations received by Adiwiyata school students on the green spatial development program campaigned through Adiwiyata schools by the Department Environment of Bangka Regency. Determination of Research Subjects (Informants), research subjects are people who are asked to provide information about a fact or opinion in accordance with the existing reality in the field. As explained by [9] the research subject is the subject the researcher is aiming for. Thus the research subject is a source of information that is extracted to reveal the facts in the field. To determine the research subject in this study using a purposive or theoretical technique, not a random or representative sample like in quantitative research. "Purposive sampling is often referred to as judgment sampling, which can simply be interpreted as selecting samples that are tailored to a specific purpose by the researcher.

According to, [10] in order to obtain more proven information, there are several criteria that need to be considered, including that the research subject is determined based on the person who is considered to know the most information needed: (i) The subject is long and intensive with an activity or activity that becomes the target or attention of the researcher. (ii) Subjects who are still fully and actively related to the environment or activities that are the target or attention of researchers. (iii) Subjects who have a fair amount of information, a lot of time and opportunity to be questioned, (iv) Subjects who are or live in the target that received treatment.

Tabel 1. List of Research Informants

\begin{tabular}{llll}
\hline No. & Name & Position & Date of Interview \\
\hline 1. & Heru & Prayoga & Kasi Bidang Penyuluhan \\
& (DLH) & & \\
4. & Ibu Bidasaari & School Members & \\
5. & Bapak Santo & Teacher & \\
\hline
\end{tabular}


The criteria determined by natural researchers to determine informants based on the above considerations are: (i) Work and activities within the government organization that is the object of research, namely the Environmental Service Office of Bangka Regency. (ii) Work and do activities such as the Chairperson and Governing Body of the NGO Flora Fauna, Bangka Regency. (iii) Work and do activities like the Chairperson and Governing Regency (iv) School Community. (v) Student's Parent.

Research Location, this research will be conducted in schools that have green spatial development programs, and researchers choose Public Elementary School (SDN) 12 and Public Elementary School (SDN) 3 Bangka Regency. The researcher chose the two schools on the grounds that the school had adopted Adiwiyata school program activities, it relatively representative enough to explore data on the subject, especially in relation to the implementation of the green spatial development campaign carried out by the Environmental Service.

Data Collection Technique, data collection techniques used in this study are; (i) Observation of participants because researchers will be directly involved to determine the level of understanding of the subject about green spatial environment. (ii) Interviews conducted in this study use semistructured interviews, by asking several questions of the data source.

\section{Result and Discussion}

Environmental management is not necessarily carried out in a short time but it should be from an early age and can be started through formal education with the goal preserving the environment through a caring and environmental culture movement in schools. Caring environment must be instilled as early as possible so that we can be responsible and love the surrounding environment, and through education we can understand how important the environment is for human life.
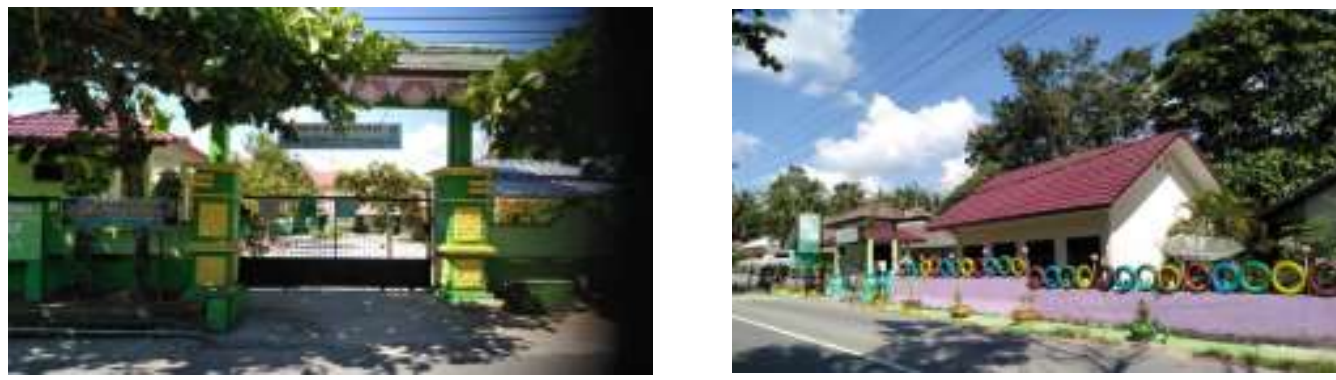

Figure $1 \& 2$ Adiwiyata School Profile

Adiwiyata School is a form of government commitment to environmental management and protection through formal education. Adiwiyata School is a tribute to the school which has succeeded in implementing the environmental care movement at school. Such as Elementary School 03 which has won the Adiwiyata award at the national level for the achievements which have transformed the school into a beautiful and green school, see picture above.

The research findings show that the campaign has a strong influence on the behavior of the school community as evidenced by the existence of a campaign through the socialization and counseling of the Adiwiyata School program. The results can be seen through the behavior of students and teachers in schools how they implementing the Adiwiyata program. It can also be seen from the attitude of the teachers who have received counseling from the Environmental Office of the 
Bangka Regency, The teacher and the member of schools enthusiastic about creating the Whatapps group as explained by Mr. Heru Prayoga, as Kasi penyuluhan bidang Adiwiyata who incharge the programs. His statemen was: "The schools that we have provided are enthusiastic about the programs implemented by the Environmental Service of the Bangka Regency Government, but since the outbreak of Covid-19, outreach activities have experienced problems in conducting outreach in schools like before the pandemic. To facilitate communication, we have created a Whatsapp group with these schools to make it easier for us to evaluate the development of ongoing activities, especially for schools that have received the Adiwiyata award" (14-09-2020).

To answer research questions related to building ethical values contained in the Public Relations Campaign in building a positive attitude towards the green spatial development program at Adiwiyata school, Mr. Heru Prayoga has also explained; "Participatory and sustainable values that must be more inculcated by all school members so that they can maintain the environmentbased on school situation for the long term, especially given the new ministerial regulation that the Adiwiyata program must be evaluated every 4 years in its term.” (14-09-2020).

Research findings regarding changes in behavior from teachers and students that students already know how they value and care for their environment by accustomed to throwing garbage in its place and planting trees in the school environment. Pak Ismi explained: "We carry out activities to make school more preety and cleans, in the other side we also do activities outside of school. we teach children how to plant, bring plants from home to be planted at school, make crafts from recycled materials, then collaborate with DLH for training students on how to compost, recycle, sort organic and inorganic waste. We also have onather activities outside of school such as going to the Pak Tulis orchid garden in Petaling planting mangroves on the beach.” (14-09-2020).

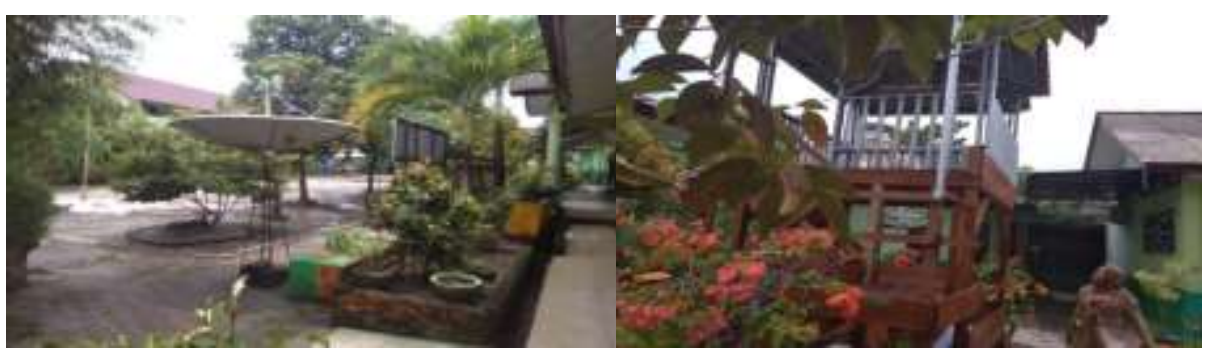

Figure 3 \& 4 Green Park and School Facility

The schools has expected or targeted at the physical environment of the school as Pak Ismi has explained We hope the school will be green, the school environment clean and beautiful, and students behave after implementing the program.

Mrs. Bidasari explained: "They are used to replacing dead plants with fresh plants, beautifying the class and the environment, they understand the benefits of green environment, so they are accustomed to maintaining cleanliness, if there are fallen leaves because of the green and shady environment during their break they will pick up leaves. -the leaves without having to be ordered. They are accustomed to throwing garbage into organic and inorganic places, and because we also make organic waste processing for fermentation" (14-09-2020) 

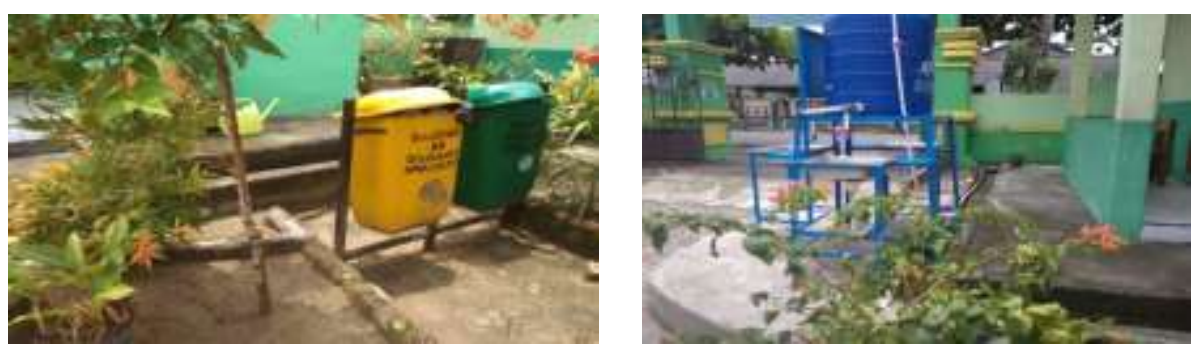

Figure 5 \& 6 Garbage collection before composting and water tower to wash hand during Covid-19

Pak Santo: "From grade I to grade 6, grade I how to select and sort waste so that there is awareness of our students to fertilize from the start, if the higher grades are already in the composting process, making recycled crafts" (14-09-2020). According to Mr. Santo: "The obstacles in the implementation of the Adiwiyata program is when the parents objected if students were often asked to bring plants to school, they had protested several times by the parents of these students entering the newspaper, but after being given an understanding by the Principal at that time, the problem was resolved and the parents understood the good intentions of the school. there have same problem about when the electricity cut of the chopping machine provided by the government did not work well at that time and the capacity of rubbish was too large, per semester we produced 100 kilos of compost, it was not in accordance with the machine wich still not enough. But then the gouverment provide the machine and now is solve the problems. "(14-09-2020).
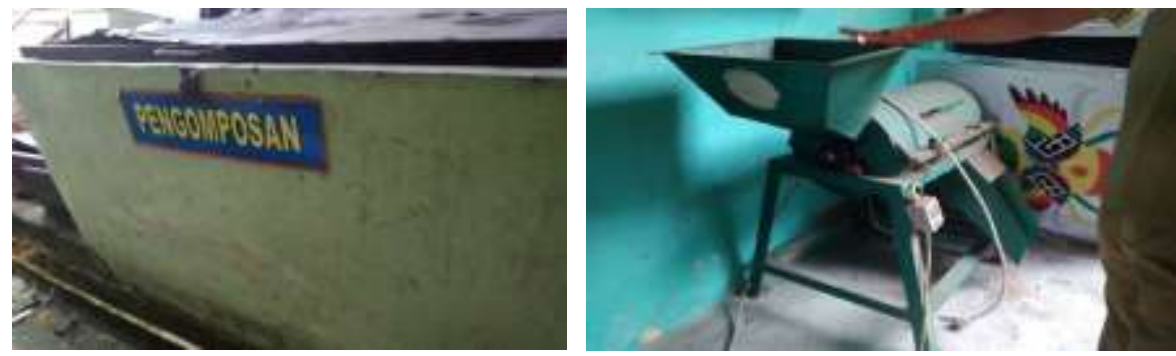

Figure 7 \& 8: Waste composting process conducted by Elementary Schools 03

\section{Conclusion}

From the results of interviews conducted by researchers with sources in the field and pictures documented by the researchers, it can be concluded that the adiwiyata school programs, which was disseminated through socialization and counseling by the Environmental Agency of the Bangka Regency, could raise awareness of the school community in maintaining a green environment and has succeeded in implementing a caring and cultural environmental movement.

\section{Reference}


[2] H. Cangara, Pengantar Ilmu Komunikasi (Cetakan Keempat). 2002.

[3] O. U. Effendy, Komunikasi Teori dan Filsafat. 2014.

[4] M. Fauzil Ali, M. Bahruddin, and T. Hanandry Dewanto, "Perancangan Iklan Kampanye Penghargaan Adiwiyata Kabupaten Gresik Melalui Animation Explainer Sebagai Upaya Meningkatkan Kesadaran Lingkungan Hidup," Desain Komun. Vis., 2015.

[5] S. Qonaah, "Strategy Kampanye Gerakan \#BijakBerplastik PT Danone Aqua Dalam Merayakan Hari Lingkungan Hidup Sedunia 2018,” J. Komun., 2019, doi: 10.31294/jkom.v10i1.5182.

[6] I. P. Putra, "Pelaksanaan Pengaturan Ruang Terbuka Hijau Dalam Rencana Tata Ruang Wilayah Di Kota Metro," J. Hima Han, 2014.

[7] R. S. S. Kramer, U. W. Weger, and D. Sharma, "The effect of mindfulness meditation on time perception," Conscious. Cogn., 2013, doi: 10.1016/j.concog.2013.05.008.

[8] B. Walgito, Pengantar Psikologi Sosial. 2010.

[9] Arikunto, "Metodelogi Penelitian, Suatu Pengantar Pendidikan," in Rineka Cipta, Jakarta, 2019.

[10] K. M. Wiig, "Knowledge Management Glossary," KNOWLEDGE RESEARCH INSTITUTE, INC. 2000. 